\title{
Role of Leadership in Managing Change at Secondary Schools of Punjab
}

\author{
Ms. Saima Malik ${ }^{1 *}$, Dr. Muhammad Zaheer Asghar ${ }^{2}$, Ms. Laila Khalid ${ }^{1}$ and Mr. Hafeez Ullah ${ }^{3}$ \\ 1Ph.D. Scholars, University of Management \& Technology, Lahore, Pakistan; \\ saimamalik666@yahoo.com, lailamohsinadeel35@gmail.com \\ 2Assistant Professor, University of Management \& Technology, Lahore, Pakistan; zaheer.asghar@umt.edu.pk \\ 3Ph.D. Scholar, University of Okara, Lahore, Pakistan; hafeezisthebest@gmail.com
}

\begin{abstract}
Objectives: To identify the role of the leader in managing change and its effect on the improvement of secondary schools. To investigate the correlation between the principal's supports for an overall change in school. Methods/statistical analysis: Quantitative research design was used in the study. The convenience sampling technique was employed to select the sample $(\mathrm{n}=150)$ of Subject Specialist Teachers (SSTs) from public schools of two districts of Punjab province. The instrument was a self-developed survey questionnaire constituting 48 items at a five-point rating scale for data collection. SPSS-16 was employed for data analysis. Factor analysis was used to recognize the common connections among different items and grouping with maximum and minimum correlations. Correlation analysis was conducted to test relationships among variables. ANOVA and t-test were applied to find out significant differences among different groups. Key findings: No effect of leadership styles was found on communication $(p=0.163)$, vision $(p=0.080)$, personal management $(p=$ $0.327)$, learning $(p=0.192)$, team building $(p=0.444)$ and planning $(p=0.067)$. However, significant impact of leadership styles was identified on decision making $(p=0.002)$, stakeholders $(p=0.046)$, budget resources $(p=0.001)$ and resistance $(p=0.005)$ with significant values. There was no significant difference found between leadership styles of male and female. Application: It is hoped that the findings of the study would be beneficial for educators in managing change through adopting effective leadership styles. It would also be helpful to indicate guidelines to newly appointed administrators for a successful administration.
\end{abstract}

Keywords: Leadership Role, Leadership Styles, Managing Change, School Improvement, Secondary Level

\section{Background}

Education is the most powerful tool that brings the desired change in the society. The better environment for educational activities is only possible due to better leadership with better strategies for providing quality education. $\underline{1}$

Leadership is determined to achieve desired goals by applying resources (human as well as material) in a proper and fruitful way. $\operatorname{In}^{\underline{3}}$ pointed out that only leaders cannot bring improvement in the institution rather they need the cooperation of their teachers too. According to, $\underline{4}$ a good leader is charismatic and generous and devoted to the organization to achieve the desired outcomes. The assumptions of "Great Man theory" is the initial point of the concept of leadership that "leaders are always born and not made". They have inbuilt qualities of leadership. The word "Man" was used because at the beginning men were only considered to be leaders. $\underline{5}$ According to, $\underline{6}$ the eminence of the leader-employee relationship has an important impact. There are five common qualities of a leader:

1. Formulate strategies $\&$ plans to achieve their visions. ${ }^{7}$

2. Communicate their visions to promote changes. $?$

${ }^{*}$ Author for correspondence 
3. Line up the people \& supporting systems by accepting their visions to make it sure that there was no hindrance in the way of providing a good environment to employees to compose their vision into reality. $\underline{8}$

4. Enable groups to perform with the new vision and sustain their commitment to achieving their highest work output so that they can work confidently for achieving the executive goals..

5. Motivate the followers to use their maximum abilities \& complete the allocated tasks within the given time limit. $\underline{7}$

Some researchers also hint leadership as a source of creating and maintaining school performance. $-\underline{-11}$ The school culture essentially depends and comprises all pillars of schools, workers, activities of employees working together and the atmosphere created by the leadership. .2 An effective leader utilizes a number of skills and chalks out plans in bringing school effectiveness. One of such leadership skills is to plan the transmission of authority to teachers and then to trust them. It will ultimately increase the academic level as well as school performance. $\underline{10}$

In $\underline{13}$ are at the standpoint that the single way of success is dependent on the appropriate application of educational leadership styles, principles, and methods for school improvement. In $\underline{14}$ states that Transformational leadership and Transactional leadership influence school and teacher separately. A distributed leadership is a form of leadership that joins the participation of all members in school development and guiding the teachers in teaching skills. $\frac{15}{\operatorname{In}} \frac{16}{}$ convinced and reported the key areas to promote a healthy culture in school:

1. Listen and respect the views of others to improve learning culture.

2. Personal respect and strengthen interpersonal relationships that will ultimately boost the professional growth

3. Competency, like the capability to produce desired results.

4. Personal integrity, sincerity, honesty and crystal clarity in the relationship.

In $\frac{17}{7}$ put these points exclusively for true leadership model. It is necessary to evolve an efficient system of educational administration to improve the quality and effectiveness of education in schools. As billions of children being educated, millions of teachers are working and a huge sum of money is being spent on them. .18 Therefore, there is a great need for change in the educational system but the question arises that who would do this? Keeping this in view, this study was designed to identify the role of leadership in managing change at the secondary level.

Diverse teaching methodologies can be useful to generate support and convince an employee to perform his role in the change process. $\frac{19}{}$ Desirable and positive changes cannot be brought in any organization without the willingness of management to participate actively, management style and leadership. $\underline{20}$ Theorists and researchers have given great importance to the dynamics of change in the new educational arena. $\underline{21}-\underline{25}$

According to $\underline{26}$ there are two types of change i.e. first order and second order change. The difference between the two can easily be pointed out as: first order change is supposed to rely on past, existing paradigm, present norms, and values while second order change is crash with past, deceit existing paradigm and conflicts with existing norms and values.

The world is facing rapid changes in all spheres of education. It has become imperative for principals, teachers, the educational organization itself to equip themselves adequately to cope with the challenges of globalization and technological revolution.

Huge challenges have been faced by the educational institutions, in this existing age, both at secondary and higher secondary levels in Pakistan. The nature of leadership is unclear and disputed due to the institutional complication, bureaucratic intervention and incapability and powerlessness to cope with diverse leadership styles. The dilemma of Pakistani educational settings is the use of fixed and traditional methods of teaching and rigid administration, in particular, in public institutions. $\underline{28}$ Leadership is a key factor that can make a difference in institutions. The effectiveness of an institution is directly and deeply related to the effectiveness of leadership and relationship among different leadership styles. $\underline{29}$

\section{Purpose of the Study}

The purpose of the study was to highlight the significance of the "Role of leadership in managing change at secondary level in Punjab province". In,, 0 believes that only effective leaders can manage rising conflicts and issues while bringing change in an organization. Teacher, at any level, is a leader and is a change agent. $\operatorname{In} \underline{31}$ are 
of the viewpoint that the teacher is the backbone of the school and education system.

\section{Objectives of the Study}

The objective of the study was:

To identify the role of the leader in managing change and its effect on school improvement.

\section{Research Questions}

Research questions of the study were:

1. What is the role of leadership in managing change at the secondary school level?

2. Is there any correlation between the principal's support and overall change in school?

3. What are the general effects of change on staff and school improvement?

\section{Method}

Data were collected from 150 Subject Specialist Teachers (SSTs) from public schools of two districts, Okara and Lahore. The sample was selected through convenience sampling technique. Survey questionnaires were distributed to 170 secondary school teachers from districts Okara and Lahore for data collection. 88\% responses of the questionnaires were returned, i.e. 150 out of 170 and were processed further to tabulate results. The major investigative areas in the survey were ideas about change, the impact of a leader's personality, leadership styles of schools' principal, leadership and change. The survey questionnaire consisted of 48 items in which 18 items were related to leadership styles, 20 items about leadership and change and 10 items of system and change. The questionnaire was designed on Likert type statements with 5 rating scales ' 1 ' was the lowest ranking and ' 5 ' was the highest ranking. The research questionnaire was validated by the experts of the field and the coefficient of Cronbach's Alpha Test was used to find out the reliability, and results indicated 0.87 internal consistency reliability. Statistical Package for Social Sciences (SPSS-16) was employed to analyze the data. Factor analysis was used to recognize the common connections among different items of questionnaire and to group the items having maximum correlations with one another and minimum correlations with other items. $\underline{32}$ Correlation analysis was conducted to test relationships among variables. The mean score of respondents on the instrument was calculated. ANOVA and t-test were applied to find out the significant differences among different groups.

\section{Data Analysis}

Teachers were 150, from which $75(50 \%)$ were females whereas $75(50 \%)$ were males. Further, in terms of qualification, 40 (26.67\%) were Graduates, 102 (68\%) were Masters and 08 (5.33\%) were M.Phil./Ph.D.

Table 1 provides the distribution of data of participants by gender. It shows that total participants are 150 in which male participants are 75 (50\%) and female participants are also 75 (50\%) of the whole sample.

Table 2 shows that total participants are 150 in which graduates are $40(26.67 \%)$, Masters are $102(68 \%)$ and MPhil/PhDs are 08 (5.33\%) of the whole sample.

Table 3 provides a comparison of the leadership styles of male and female participants. It shows that there is no difference between male and female leadership styles at the secondary level because of all non-significant values.

Table 4 shows that there is no significant difference between different leadership styles at a secondary level due to non-significant values.

Table 5 provides a comparison of the leadership styles of male and female participants. It shows no difference between male and female leadership styles at the secondary level.

Table 6 provides the correlation of different leadership styles on different factors of change of male and female

Table 1. Demographic gender of participation

\begin{tabular}{|l|c|c|}
\hline Respondents & N & Percentage \\
\hline Gender & 75 & $50 \%$ \\
\hline Female & 75 & $50 \%$ \\
\hline Male & 150 & $100 \%$ \\
\hline All &
\end{tabular}

Table 2. Educational background of participants

\begin{tabular}{|l|c|c|}
\hline Qualification & N & Percentage \\
\hline Graduation & 40 & $26.67 \%$ \\
\hline Masters & 102 & $68 \%$ \\
\hline MPhil/PhD & 08 & $5.33 \%$ \\
\hline All & 150 & $100 \%$ \\
\hline
\end{tabular}


Table 3. Comparison of leadership styles of head teachers

\begin{tabular}{|l|l|c|c|c|}
\hline \multicolumn{2}{|l|}{ Respondents } & N & Mean & SD \\
\hline \multirow{2}{*}{ Commanding } & Male & 75 & 3.51 & .856 \\
\cline { 2 - 5 } & Female & 75 & 3.46 & .827 \\
\hline \multirow{3}{*}{ Affirmative } & Male & 75 & 3.68 & 1.01 \\
\cline { 2 - 5 } & Female & 75 & 3.54 & .926 \\
\hline \multirow{3}{*}{ Disionary } & Male & 75 & 3.47 & .892 \\
\cline { 2 - 5 } & Female & 75 & 3.50 & .834 \\
\hline \multirow{3}{*}{ Coaching } & Male & 75 & 3.46 & .983 \\
\cline { 2 - 5 } & Female & 75 & 3.47 & .938 \\
\hline \multirow{2}{*}{ Peace setting } & Male & 75 & 3.44 & .938 \\
\cline { 2 - 5 } & Female & 75 & 3.55 & .829 \\
\cline { 2 - 5 } & Male & 75 & 3.42 & 1.00 \\
\cline { 2 - 5 } & Female & 75 & 3.54 & .819 \\
\hline
\end{tabular}

participants. It shows that there is higher correlation $(\mathrm{r}$ $=0.335)$ between commanding \& decision, $(\mathrm{r}=0.157)$ between affirmative \& vision, $(r=0.249)$ between visionary \& budgeting resources, $(r=0.309)$ between democratic \& budgeting resources, $(r=0.183)$ between coaching \& resistance, $(r=0.293)$ between peace setting $\&$ budgeting resources.

Table 7 analyzes the relationship between different leadership styles and change. It shows there is no impact of leadership on communication with a significant value of 0.163 .

Table 8 shows there is no impact of leadership on vision with a significant value of 0.80 . The relationship between different leadership styles and change was analyzed.

Table 9 shows there is no impact of leadership on personal management with significant value of 0.327 . The relationship between different leadership styles and change was analyzed.

Table 10 shows there is no impact of leadership on learning with a significant value of 0.192.1. The relationship between different leadership styles and change was analyzed.

Table 11 shows there is no impact of leadership on team-building with a significant value of 0.444 . The relationship between different leadership styles and change was analyzed.

Table 12 shows there is no impact of leadership on planning with a significant value of 0.067 . The relationship

Table 4. ANOVA

\begin{tabular}{|c|c|c|c|c|c|c|}
\hline & & Sum of Squares & Df & Mean Square & $\mathbf{F}$ & Sig. \\
\hline \multirow[t]{3}{*}{ Commanding } & Between groups & 3.008 & 6 & .501 & \multirow{3}{*}{.703} & \multirow{3}{*}{.648} \\
\hline & Within groups & 102.029 & 143 & .713 & & \\
\hline & Total & 105.037 & 149 & & & \\
\hline \multirow[t]{3}{*}{ Affirmative } & Between groups & 2.548 & 6 & .425 & \multirow{3}{*}{.440} & \multirow{3}{*}{.851} \\
\hline & Within groups & 137.989 & 143 & .965 & & \\
\hline & Total & 140.537 & 149 & & & \\
\hline \multirow[t]{3}{*}{ Visionary } & Between groups & 4.109 & 6 & .685 & \multirow{3}{*}{.920} & \multirow{3}{*}{.483} \\
\hline & Within groups & 106.490 & 143 & .745 & & \\
\hline & Total & 110.599 & 149 & & & \\
\hline \multirow[t]{3}{*}{ Democratic } & Between groups & 3.422 & 6 & .570 & \multirow{3}{*}{.612} & \multirow{3}{*}{.720} \\
\hline & Within groups & 133.245 & 143 & .932 & & \\
\hline & Total & 136.667 & 149 & & & \\
\hline \multirow[t]{3}{*}{ Coaching } & Between groups & 7.986 & 6 & 1.331 & \multirow{3}{*}{1.756} & \multirow{3}{*}{.112} \\
\hline & Within groups & 108.356 & 143 & .758 & & \\
\hline & Total & 116.341 & 149 & & & \\
\hline \multirow[t]{3}{*}{ Peace setting } & Between groups & 2.723 & 6 & .454 & .532 & .784 \\
\hline & Within groups & 122.084 & 143 & .854 & & \\
\hline & Total & 124.807 & 149 & & & \\
\hline
\end{tabular}


Table 5. Comparison of different leadership styles

\begin{tabular}{|l|c|c|c|c|c|c|}
\hline Commanding & Affirmative & Vision & \multicolumn{2}{|c|}{ Democratic } & Coaching & Peace setting \\
\hline P value & .747 & .387 & .593 & .955 & .560 & .424 \\
\hline
\end{tabular}

Table 6. Relationship between leadership styles and change

\begin{tabular}{|l|c|c|c|c|c|c|c|c|c|c|}
\hline & Communication & Vision & $\begin{array}{c}\text { Personal } \\
\text { Management }\end{array}$ & $\begin{array}{c}\text { Team } \\
\text { Building }\end{array}$ & Planning & $\begin{array}{c}\text { Decision } \\
\text { Making }\end{array}$ & $\begin{array}{c}\text { Stake } \\
\text { Holder }\end{array}$ & Learning & $\begin{array}{c}\text { Budget } \\
\text { Resources }\end{array}$ & Resistance \\
\hline Commanding & $.226^{* *}$ & $.239^{* *}$ & $.191^{*}$ & 0.088 & $.174^{*}$ & $.335^{* *}$ & $.218^{* *}$ & 0.137 & $.213^{* *}$ & $.307^{* *}$ \\
\hline Affirmative & 0.003 & 0.157 & 0.028 & 0.088 & 0.066 & 0.127 & 0.11 & 0.104 & 0.146 & 0.027 \\
\hline Visionary & 0.076 & 0.143 & 0.087 & 0.095 & 0.053 & $.192^{*}$ & 0.151 & 0.06 & $.249^{* *}$ & $.200^{*}$ \\
\hline Democratic & 0.029 & 0.111 & 0.101 & 0.084 & 0.036 & $.219^{* *}$ & $.180^{*}$ & $.178^{*}$ & $.309^{* *}$ & $.185^{*}$ \\
\hline Coaching & 0.08 & 0.088 & 0.128 & 0.087 & 0.037 & $.162^{*}$ & 0.155 & 0.059 & 0.1 & $.183^{*}$ \\
\hline Peace setting & 0.059 & 0.138 & 0.07 & $.189^{*}$ & $.203^{*}$ & $.211^{* *}$ & $.227^{* *}$ & $.179^{*}$ & $.293^{* *}$ & 0.105 \\
\hline
\end{tabular}

${ }^{*} \mathrm{p}<.05,{ }^{* *} \mathrm{p}<.01$

Table 7. Impact of leadership styles on Communication

\begin{tabular}{|l|c|c|}
\hline Respondents & N & Sig. \\
\hline Overall & 150 & 0.163 \\
\hline
\end{tabular}

Table 8. Impact of leadership styles on vision

\begin{tabular}{|l|c|c|}
\hline Respondents & N & Sig. \\
\hline Overall & 150 & 0.080 \\
\hline
\end{tabular}

Table 9. Impact of leadership styles on Personal Management

\begin{tabular}{|l|c|c|}
\hline Respondents & N & Sig. \\
\hline Overall & 150 & 0.327 \\
\hline
\end{tabular}

Table 10. Impact of leadership styles on learning

\begin{tabular}{|l|c|c|}
\hline Respondents & N & Sig. \\
\hline Overall & 150 & 0.192 \\
\hline
\end{tabular}

Table 11. Impact of leadership styles on team building

\begin{tabular}{|l|c|c|}
\hline Respondents & N & Sig. \\
\hline Overall & 150 & 0.444 \\
\hline
\end{tabular}

between different leadership styles and change was analyzed.

Table 13 shows there is an impact of leadership on decision making with a significant value of 0.002 . The relationship between different leadership styles and change was analyzed.
Table 14 shows there is an impact of leadership on stack holders with a significant value of 0.046 . The relationship between different leadership styles and change was analyzed.

Table 15 shows there is an impact of leadership on budget resources with a significant value of 0.001 . The relationship between different leadership styles and change was analyzed.

Table 16 shows there is an impact of leadership on resistance with a significant value of 0.005 . The

Table 12. Impact of leadership styles on planning

\begin{tabular}{|l|c|c|}
\hline Respondents & N & Sig. \\
\hline Overall & 150 & 0.067 \\
\hline
\end{tabular}

Table 13. Impact of leadership styles on decision making

\begin{tabular}{|l|c|c|}
\hline Respondents & N & Sig. \\
\hline Overall & 150 & 0.002 \\
\hline
\end{tabular}

Table 14. Impact of leadership styles on stakeholders

\begin{tabular}{|l|c|c|}
\hline Respondents & N & Sig. \\
\hline Overall & 150 & 0.046 \\
\hline
\end{tabular}

Table 15. Impact of leadership styles on budget resources

\begin{tabular}{|l|c|c|}
\hline Respondents & N & Sig. \\
\hline Overall & 150 & 0.001 \\
\hline
\end{tabular}


Table 16. Impact of leadership styles on resistance

\begin{tabular}{|l|c|c|}
\hline Respondents & N & Sig. \\
\hline Overall & 150 & 0.005 \\
\hline
\end{tabular}

relationship between different leadership styles and change was analyzed.

\section{Conclusions}

Following conclusions were derived on the basis of findings:

No impact of leadership was found among communication, vision, personal management, learning, team building and planning with non-significant values. A significant impact of leadership was found among decision making, stakeholders, resources and resistance with significant values.

Thus, it was concluded that there was a higher correlation between commanding \& decision making, affirmative \& vision, visionary \& budgeting resources, democratic \& budgeting resources, coaching \& resistance and between peace setting \& budgeting resources. No significant difference was found on different leadership styles of males and females as it is a prevailing perception of stereotyped mindset in the society.

\section{Implications}

No significant difference was revealed on different leadership styles of males and females in this study. According to the results of the study, the stereotype assumption of society is negated that the leadership style of men is better than women. In our education system, the higher correlation between commanding \& decision making, affirmative \& vision, visionary \& budgeting resources, democratic \& budgeting resources, coaching \& resistance and between peace setting \& budgeting resources can be followed to bring effective change in the schools. It can also reduce resistance to bring a new change in the organization.

It originally depends on the skills of the leader to manage change in any organization, otherwise, it becomes tough to be efficient and speedy in meeting the rapid changes of the world. Implementation of the results of this study can bring a considerable change in the institution and as a result, the institute will flourish.
The findings of the study would prove effective for future researchers as they will be having a clear picture of leadership in managing change at the secondary level in schools of Punjab. Data was collected from only two districts of Province Punjab on account of rare resources and accessibility. Future researchers could research with the larger sample. This research would provide a substantial and comprehensive literature review for researchers. It would also be helpful to specific guidelines to newly appointed administrators for a successful administration.

\section{References}

1. Hopkins D, Reynolds D. The past, present and future of school improvement: towards the third age. Br Educ Res J. 2001;27(4):459-75.

2. Educational management, planning and supervision: model for effective implementation. [cited 2013 Aug]. https://www.researchgate.net/publication/282980192_ Educational_management_planning_and_supervision_ model_for_effective_implementation.

3. Danielson C. The many faces of leadership. Educ Leadersh. 2007;65(1):14-19.

4. Jenkins T. Reflections on Kenneth E. Boulding's the image: glimpsing the roots of peace education pedagogy. J Peace Educ Soc Justice. 2013;7(1):27-37.

5. What is leadership? [cited 2004]. https://www.mindtools. com/pages/article/newLDR_41.htm.

6. De Cremer D. Why inconsistent leadership is regarded as procedurally unfair: the importance of social self-esteem concerns. Eur J Soc Psychol. 2003;33(4):535-50.

7. Mulford B. Organizational learning and educational change. Extending educational change; 1991. P. 336-61.

8. The culture of the school and the problem of change. [cited 1996]. http://www.daneshnamehicsa.ir/userfiles/file/ Resources/5-1)\%20Change/INTRO_\%20Revisiting\%20 The $\% 20$ Culture $\% 20$ of $\% 20$ the $\% 20$ School.pdf.

9. Leading in a culture of change. [cited 2007 Feb 02].https://www. amazon.com/Leading-Culture-Change-Michael-Fullan/ $\mathrm{dp} / 0787987662$.

10. Building leadership capacity for school improvement. [cited 2003 May 01]. https://www.amazon.com/ Building-Leadership-Capacity-School-Improvement/ dp/033521178X.

11. Building the capacity for leading and learning. [cited 2003]. https://www.researchgate.net/publication/249751839_ Distributed_Leadership_and_School_Improvement Leading_or_Misleading.

12. Leading in a culture of change personal action guide and workbook. [cited 2003 Dec 05]. https://www.amazon. 
com/Leading-Culture-Change-Personal-Workbook/ dp/0787969699.

13. Amanchukwu RN, Stanley GJ, Ololube NP. A review of leadership theories, principles and styles and their relevance to educational management. Management. 2015;5(1):6-14.

14. Pan HL. Leadership for school improvement. Management in Education. 2014;28(3):101-5.

15. Spillane JP, Halverson R, Diamond JB. Towards a theory of leadership practice: a distributed perspective. J Curric Stud. 2004;36(1):3-34.

16. Building a new structure for school leadership. [cited 2000]. http://www.shankerinstitute.org/sites/shanker/files/ building.pdf.

17. Lovely SD. Making the leap to shared leadership. Learn Prof. 2005;26(2):16.

18. The adventure of leadership: an unorthodox business guide. [cited 2003 Jun 02]. https://www.amazon.com/ Adventure-Leadership-Unorthodox-Business-Guide/ dp/059527028X.

19. Stanley DJ, Meyer JP, Topolnytsky L. Employee cynicism and resistance to organizational change. J Bus Psychol. 2005;19(4):429-59.

20. Management and organizational change. [cited 2011]. https://www.inc.com/encyclopedia/managingorganizational-change.html.

21. Beyond educational reform: bringing teachers back in. [cited 1997 Oct 01]. https://www.amazon.com/ Beyond-Educational-Reform-Bringing-Teachers/ dp/033519995X.

22. The six secrets of change: Jossey-Bass. [cited 2008]. http:// michaelfullan.ca/wp-content/uploads/2016/06/2008SixSec retsofChangeKeynoteA4.pdf.

23. The challenge of change: start school improvement now! [cited 2009 Apr 09]. https://www.amazon.
com/Challenge-Change-Start-School-Improvement/ $\mathrm{dp} / 1412953766$.

24. Levin B. The challenge of large-scale literacy improvement. Sch Eff Sch Improv. 2010;21(4):359-437.

25. Harris A. Big change question: does politics help or hinder education change? J Educ Change. 2009;10:63-7.

26. School leadership that works: from research to results. [cited 2001 Sep 09]. https://www.amazon.in/ School-Leadership-That-Works-Research-ebook/dp/ B0042JTB1E.

27. Managing change in organizations. [cited 2003 Apr 30]. https://www.amazon.com/Managing-OrganizationalChange-Patrick-Connor/dp/1567205100.

28. Leadership development in the context of Sind Pakistan at secondary school level: an exploratory study. [cited 2015]. http://prr.hec.gov.pk/jspui/handle/123456789/2036.

29. The impact of leadership styles on the performance of Academicians. [cited 2015 Jan] https://www.researchgate. net/publication/313765838_The_Impact_of_Leadership_ Styles_on_Academicians'_Commitment_in_Higher_ Educational_Institutions.

30. Corporate cultures, the rites and rituals of corporate life. [cited 2000 May 19]. https://www.amazon.com/ Corporate-Cultures-Rites-Rituals-Life/dp/0738203300.

31. Schools and society: a sociological approach to education. [cited 2014 Feb 21]. https://www.amazon. com/Schools-Society-Sociological-Approach-Education/ $\mathrm{dp} / 1452275831$.

32. Researchdesign:qualitative, quantitative, andmixedmethods approaches. [cited 2017]. https://www.amazon.com/ Research-Design-Qualitative-Quantitative-Approaches/ $\mathrm{dp} / 1452226105$. 